\title{
No hea koe? Where are you from?
}

\author{
Keywords \\ Mokomoko, Te Whakatōhea, Ōpōtiki, New Zealand Land wars, Māori Land Wars.
}

"Me tiro whakamuri, ki te haere whakamua. We must look to our past in order to move forward." This whakataukī (proverb) speaks to Māori perspective of time and the importance of knowing your own history in order to move forward. We must look to our past and move as if we are walking backwards into our future. The present and past are certain, however, the future is unknown. Tangohia mai te taura: Take This Rope - is a practice-led research project, that enquires into a disputed narrative of the past. The thesis study involves researching, directing and producing a feature documentary about historical grievances within Te Whakatōhea and Te Whānau ā Mokomoko. The project artistically explores the potentials of documentary form in relation to Mātauranga Māori (Māori customs and knowledge) and kaupapa Māori (Māori research approaches). The research seeks to exhume stories from iwi members and question certain Pākehā constructed narratives (The Church Missionary, 1865; Taylor, 1868; McDonnell, 1887: Grace, 1928). Accordingly, the documentary will communicate outwards from accumulated experience and storytelling within my whānau. Thus, it will interweave the narratives of people whose whakapapa (genealogy) has been interwoven with historical events and their implications, related to the execution of my ancestor Mokomoko in 1866, and the preceding murder of the Reverend Carl Sylvius Völkner in 1885. Artistically and theoretically, the project constructs a new form of Māori documentary through a consideration of pūrākau (Pouwhare \& McNeill 2018). The significance of the study lies in the potential to rethink documentary form based on the tenets of pūrākau. In so doing, the study will not only expand the corpus of research about Mokomoko but also extend how indigenous documentaries might be thought of as structures. Four key concepts that will guide the development of the film are: WHAKAPAPA - GENEALOGY: Through genealogy, it builds my personal connection with the film, the interviewees and the community. But it also holds a strong responsibly for me to complete this film with the utmost respect and care. WHENUA \& WHANAU - LAND \& FAMILY: With land and family at the centre of the film. Embodiment is an important part of how this film is created. I reconnected more with my extended family and actively seek out opportunities to attend wānanga (discussions) and perform kapa haka (Māori performing arts) specific to our land and family. TIKANGA - CUSTOMS: The process and structures of making this film have followed tikanga Māori (Māori customs). Practising karakia and waiata (Māori prayers and songs) to perform before and after we film were key customs we believe are important when creating this film. These protocols are practised by the crew and affirm our rōpu (group) as a family. KOHA - RECIPROCATION: Unlike traditional filming structures that schedule films to be completed in an economically and efficient way. Koha reinforces the concept of reciprocation, to give and receive. As the community gifts their time and stories, the film will be gifted back to those from which it came. Myself as the ringa toi (artist) must make conscious effort to go back to the iwi (local tribe) and being an active member within the town and supporting community initiatives. In addition, the study will demonstrate how the process of documentary making inside iwi can function as a form of raranga (weaving) where collaborating fragments may take form and through this increase feelings of value, healing, and historical redress. 